\title{
Health Services Users with Diabetes Mellitus: From Knowledge to the Use of Healthcare Rights
}

\author{
Ellen Cristina Barbosa dos Santos ${ }^{1}$ \\ Carla Regina de Souza Teixeira² \\ Maria Lucia Zanetti ${ }^{3}$ \\ Manoel Antonio dos Santos ${ }^{4}$ \\ Marta Cristiane Alves Pereira ${ }^{2}$
}

This descriptive study with qualitative approach analyzes the knowledge of individuals with diabetes mellitus (DM) concerning their health rights. Open interviews were conducted with 12 individuals with DM in a university center in the interior of Sao Paulo, Brazil. Content analysis enabled the identification of two categories: the users' (lack of) knowledge concerning their rights and the unaware exercise of their rights. The results revealed that despite the legal advancements achieved in public policies, most users with DM are unaware of their rights, although they use the benefits that accrue from law in an unconscious way. Providing complete and sufficient information is essential so that individuals are able to make the best decision in relation to their treatment, preserving their autonomy.

Descriptors: Nursing; Diabetes Mellitus; Patient Rights; Public Policies.

${ }^{1}$ RN, M.Sc. in Nursing, Assistant Professor, Universidade Federal de Pernambuco, PE, Brazil.

${ }^{2}$ RN, Ph.D. in Nursing, Professor, Escola de Enfermagem de Ribeirão Preto, Universidade de São Paulo, WHO Collaborating Centre for Nursing Research Development, SP, Brazil. E-mail: Carla - carlast@eerp.usp.br.

${ }^{3}$ RN, Ph.D. in Nursing, Associate Professor, Escola de Enfermagem de Ribeirão Preto, Universidade de São Paulo, WHO Collaborating Centre for Nursing Research Development, SP, Brazil. E-mail: zanetti@eerp.usp.br.

${ }^{4}$ Psychologist, Ph.D. in Psychology, Professor, Faculdade de Filosofia, Ciências e Letras de Ribeirão Preto, Universidade de São Paulo, SP, Brazil. 5 RN, Ph.D. in Nursing, Professor, Escola de Enfermagem de Ribeirão Preto, Universidade de São Paulo, WHO Collaborating Centre for Nursing Research Development, SP, Brazil.

Corresponding Author:

Carla Regina de Souza Teixeira

Universidade de São Paulo. Escola de Enfermagem de Ribeirão Preto.

Departamento de Enfermagem Geral e Especializada

Av. dos Bandeirantes, 3900

Bairro: Monte Alegre

CEP: 14040-902 Ribeirão Preto, SP, Brasil

E-mail: carlast@eerp.usp.br 


\title{
Usuários dos serviços de saúde com diabetes mellitus: do conhecimento à utilização dos direitos à saúde
}

Estudo descritivo de abordagem qualitativa, e teve como objetivo analisar o conhecimento dos usuários dos serviços de saúde com diabetes mellitus (DM), acerca dos seus direitos. Participaram 12 pessoas com DM, atendidas em um centro universitário do interior paulista, em 2008, por meio de entrevista aberta. A análise de conteúdo temática dos dados possibilitou identificar duas categorias: o (des)conhecimento dos usuários dos serviços de saúde com diabetes sobre seus direitos e o exercício não consciente dos seus direitos pelas pessoas com DM. Foi possível constatar que, apesar dos avanços legalmente alcançados pelas políticas públicas, a maioria dos usuários dos serviços de saúde com DM desconhece seus direitos, embora utilize, de maneira não consciente, os benefícios advindos da legislação. Ressalta-se como ponto fundamental prover informações completas, suficientes para que a pessoa possa tomar a melhor decisão em relação ao seu tratamento, preservando sua autonomia, nos serviços de saúde.

Descritores: Enfermagem; Diabetes Mellitus; Direitos do Paciente; Políticas Públicas.

\section{Usuarios de los servicios de salud con diabetes mellitus: del conocimiento a la utilización de los derechos a la salud}

\begin{abstract}
Se trata de un estudio descriptivo de abordaje cualitativo, con el objetivo de analizar el conocimiento de los usuarios de los servicios de salud con diabetes mellitus (DM) acerca de sus derechos. Participaron 12 personas con DM atendidas en un centro universitario del interior paulista en 2008, por medio de entrevista abierta. El análisis de contenido temático de los datos posibilitó identificar dos categorías: el (des)conocimiento de los usuarios de los servicios de salud con diabetes sobre sus derechos y el ejercicio no consciente de sus derechos por las personas con DM. Fue posible constatar que, a pesar de los avances legalmente alcanzados por las políticas públicas, la mayoría de los usuarios de los servicios de salud con DM desconoce sus derechos, a pesar de que utilizan los beneficios provenientes de la legislación, de manera no consciente. Se resalta como punto fundamental proveer informaciones completas y suficientes para que la persona pueda tomar la mejor decisión en relación a su tratamiento, preservando su autonomía en los servicios de salud.
\end{abstract}

Descriptores: Enfermería; Diabetes Mellitus; Derechos del Paciente; Políticas Públicas.

\section{Introduction}

Diabetes Mellitus (DM) is a chronic disease with severe complications and great complexity, making the necessary means to control the disease very costly, not only for those affected and their families but also for the health system ${ }^{(1)}$. Therefore, it is necessary to establish public policies creating mechanisms to minimize both the onset and worsening of the disease to reduce the costs that accrue without early detection and from complications related to the difficulty of maintaining metabolic control in the presence of $\mathrm{DM}^{(2)}$.
In this context, Federal Law no $11.347 / 06$ was enacted on September $29^{\text {th }}$ 2007. It provides for the free distribution of medication and supplies necessary to apply insulin and monitor capillary glucose in DM patients registered in diabetes educational programs ${ }^{(3)}$. Attempting to detail and regulate the free distribution of benefits that accrue from this law, decree no 2.583/07 defines the set of medication and supplies that should be provided to DM patients within the scope of the Single Health System (SUS) ${ }^{(4)}$. 
However, for the rights of DM patients provided by the law to be met, these need to be disseminated and known by the population and even the health professionals themselves. Therefore, it is the responsibility of all health professionals as pro-active individuals to incorporate a reflective and ethical attitude that includes the adoption of new knowledge and skills necessary for effective communication with health services users. The establishment of efficient communication between patients and health professionals is one of the guiding axes of bioethics ${ }^{(5)}$, a relatively recent discipline that has gained increasing prominence in recent years.

Given the need to redirect care practices, a discussion encouraged by those in the field of bioethics is that patients should exercise their rights seeking to achieve the humanization of health services and also to ensure the exercise of citizenship in health. Bioethics poses questions concerning humanization and the customization of health services and also the promotion of patients' rights. In this context, the right to health becomes the highest value in the bioethical paradigm ${ }^{(5)}$.

There are two ways to promote the humanization of health services and ensure DM patients' rights in the health services. The first is to ensure access to information concerning their legal rights as citizens, which should be provided by a qualified health team. The second refers to the supply and appropriate allocation of resources so that access is fair and equitable.

Both users and heath professionals need to have knowledge of users' rights so that a democratic, responsible and reflective awareness of citizens is possible; knowing their rights is the first step to diminish the barriers faced by DM patients to acquire full access to their rights as citizens(6). From this perspective, this study investigated the knowledge of DM patients who are users of health services, concerning their rights and how they have appropriated these health rights ensured by current law.

\section{Theoretical Framework}

Principlist Biothetics( 7 ) and the official documents concerning the health rights of patients with diabetes that regulate the free distribution of medication and supplies necessary to its application and monitoring of capillary glucose grounded this study ${ }^{(3-4)}$.

The Principlist Biothetical model is based on essential principles that are defined as: autonomy, beneficence, nonmaleficence and justice. 'Autonomy' is the ability one has to self-govern oneself, to use her/ his freedom of choice and act according to her/his own will. 'Beneficence' is intrinsically related to the ethical behavior of doing good, promoting people's wellbeing. 'Nonmaleficence' is related to the need to prevent and remove potential harm from people; it is not to do evil. The principle of justice implies an equitable distribution of health goods, benefits and services ${ }^{(7)}$.

Currently, people with DM have a great variety of medication, supplies and devices available to control the disease. The creation of standards and routines credited and validated by laws and decrees can become active and efficacious laws supported by current ethical thinking that includes social participation and the full exercise of citizenship.

However, it is not only about the building standards, regulations or laws, but about taking into account of how feasible it is to implement these devices in order to ensure better metabolic control of people with DM, giving priority to the individuality of each human being and enabling the formation of citizens capable of exercising their rights with autonomy.

The need to provide appropriate information to health services' users refers to nursing's social role. Information is part of the care delivered to users, and providing appropriate guidance is a fair attitude so that they can seek resources that society has put at their disposal for treatment( ${ }^{(8)}$.

Current discussions, stemming from the formalization of patients' rights, refer to bioethics as the moderator of health actions and of the repercussions of these actions, leading to reflections concerning the rights of users, access to these rights and the dissemination of information related to the appropriate use of these in the health services.

When equity is considered as a principle that enables the right to health closely interconnected with the bioethical principle of justice, since it promotes the acknowledgment of different needs that originated from diverse individuals to achieve equal rights $^{(9)}$, we observe that the allocation of resources by SUS for DM patients follows such a principle. It is evidenced, for example, by the recommendations for monitoring capillary glucose. Type 2 DM patients who use oral anti-diabetics should monitor their glucose at the health unit itself. Type 1 DM patients have the right to receive a glucometer and test strips from the health service, necessary for performing capillary glucose tests at home ${ }^{(4)}$. Therefore, the distribution of benefits in healthcare should consider each user and his/her specific needs to control the disease, which requires respect for equity and distributive justice. 
From this perspective, discussing issues related to the allocation of resources permit the systematization of strategies that benefit the deconstruction and/ or improvement of current practices contributing to ensuring that DM patients exercise their citizenship within the scope of distributive justice. In this context, bioethical principles, also included in the Code of Ethics for Nursing Professionals, should permeate all nursing actions and guide nurse practice with any patient ${ }^{(8)}$, in particular those with DM who have already conquered their space with the formulation of specific laws that legitimate and protect their interests.

However, this law is still in the implementation phase, which requires studies addressing the practicability and feasibility of these laws in our context, and investigating the perception of DM patients concerning these laws and their implications in their daily routine and care. The knowledge of users about their rights and the way they have appropriated benefits ensured by current laws can support the planning of strategies to evaluate implemented programs.

\section{Method}

This is an exploratory, descriptive and crosssectional study with a qualitative approach. It was carried out in a Research Center and University Extension in the interior of São Paulo, Brazil. The inclusion criteria were: health services' users older than 18 years of age, who attended the Diabetes Education Group between August and December 2008 and consented to participate in the study. The criterion for choosing the users was accessibility, according to the availability of people for the interview, thus a convenience sample. It is worth noting that this educational group was not linked to the city's Capillary Glucose Monitoring Program but cared for people with DM who freely sought the service after the program was advertised in the media.

Because it is a qualitative study, the criterion of sample representativeness for ceasing data collection was not numerical, but rather the criterion of data saturation was adopted where variability allowed addressing the totality of the studied problem in its multiple dimensions. The sample is considered exhausted or satisfactory when deep responses are given to the questions in association with repeated reports obtained from other interviewees ${ }^{(10)}$. Saturation of reports was achieved in this study with 12 interviews held with adult individuals with DM, all heath service users, concerning their rights. Participants were individually interviewed in a private and comfortable room for an average of 30 minutes.

Data collection was carried out from September to December 2008. The researcher invited the patients to participate in the study and collected data after they had attended the group activity. An open interview with two guiding questions was held and recorded to ensure the reliability of the answers and transcribed verbatim afterwards. The following guiding questions were used: What information do you have concerning your rights as an individual with diabetes? How do you use these rights?

Reports were fully transcribed and the empirical material was exhaustively read. Afterwards, excerpts were selected according to relevance criteria and then composed the units of meaning, which were codified and organized in categories relating them to the themes ${ }^{(10)}$. The analysis of themes was based on official documents identified through a search of the rights of individuals with DM, users of health services and the principles of bioethics.

The research project was approved by the Research Ethics Committee at the University of São Paulo at Ribeirão Preto, College of Nursing, protocol 0869/2008. The interviewees signed free and informed consent terms. The names mentioned in the participants' reports were replaced by fictitious names. Codes (E1, E2, ...) were used to designate each interviewee in order to ensure confidentiality.

\section{Results and Discussion}

The following theme emerged from the analysis of the reports: lack of awareness of health services users with DM concerning their rights. This theme encompasses two categories: (1) The (lack of) knowledge of health services users with DM concerning their rights and (2) The health services users' unconscious exercise of rights.

\section{(Lack of) knowledge of health services users with DM concerning their rights}

"Lack of knowledge" refers to the users' lack of awareness concerning their healthcare rights. In relation to this theme, the participants' reports implied that despite the legal advancements achieved by public policies, most of the users of health services with DM do not know their rights. The principle of autonomy ensures the right of people to have their own point of view, to make choices and decisions based on their personal beliefs and values(7). Therefore, respecting the 
autonomy of people means to provide all the necessary information for them to make the best decision possible according to their interests.

This study's findings evidenced a generalized lack of knowledge of users about their rights, which can be verified in the following report:

My rights as a user with diabetes? Look, I don't know about any right. I don't know. (E4)

In a study addressing the motives that lead nurses to interfere in the autonomy of users with chronic diseases, the following motives were identified: not acknowledging the patients' ability of autonomy, the users' lack of knowledge about their rights, and the users' profile of dependency, among others ${ }^{(11)}$.

Hence, it seems there is still lack of access or understanding of information for health services users, having knowledge of their rights, to fully exercise these rights as citizens in a context in which justice and equity are essential to correct healthcare inequalities. For that, one needs to take into account that information and knowledge are essential public goods and unequal access to these goods is an important determinant of potential healthcare inequalities ${ }^{(12)}$.

The challenge in the Brazilian context is to put into practice achievements established in the legal scope ${ }^{(13)}$. Within what is called process of constructing healthcare rights, an essential aspect is to build a health consciousness, understood as "the awareness that healthcare is a people's right"(14), which can be evidenced in the following report:

I don't even know what the rights are that I have as a diabetic person. I confess that I didn't know that I had such rights. So, I can't know anything. (E6)

Additionally, the problem of rights appear on paper but fall to be made concrete and the perception that there are inequities in Brazil in relation to the distribution of healthcare goods ${ }^{(13)}$ appear in the report of one user as follows:

Well, if you look at the Brazilian constitution, I have every right to health, but in reality I don't. Health in Brazil is chaos, even though here it [referring to the local context] is good, a little better. But if you go to other places, the situation is very sad. (E2)

From this perspective, we believe that the democratization of knowledge, understood as the promotion of conscious and critical access to information, goods and healthcare supplies, can empower citizens and permit them to participate in decisions related to the definition and implementation of policies that ensure them the right to healthcare ${ }^{(15)}$. With the incorporation of information, mediated by a critical and reflective awareness, exercised by individuals who appropriate their citizenship privileges, people can judge situations, exercise their rights and behave as proactive and autonomous citizens. By autonomy, a basic bioethical principle, we understand the self-government and selfdetermination of people to make decisions related to their lives, health and physical-emotional integrity and social relationships, implying the existence of options and freedom of choice, which requires individuals to be able to act in accordance with their decisions (7). The following example portrays the perception of one user concerning the importance of acknowledging one's rights in order to autonomously and consciously position oneself.

When you are aware of your rights, you have more autonomy to demand your rights. We only claim what we know is our right, you know? That's why I guess that everyone has to have access to such information, about our rights. (E4)

Knowledge leads people to fulfill their rights, which strengthens their social participation, which is one of the SUS's organizing principles. From the perception of the following user, being aware of one's rights confers on users the possibility of being dignified or at least to receive an explanation from health professionals when, for example, there is a lack of medication:

I think there are people, who sometimes, if they don't have a little knowledge... They [those working in the pharmacy] treat them well, but when the person [health service user] says: "When it is going to be here" They [those working in the pharmacy] say: I don't know, wait." It's not like that, you know? If it's a citizen's right, you have to give some explanation, like: look, it is going to be here on..."I see that if you don't have a little knowledge, it's a problem. (E4)

From this perspective, "ignoring the information needs of a patient is a form of cruelty" and contradicts the bioethical principle of the nonmaleficence. This principle consists of the obligation to not harm people. Therefore, not informing users about their rights contradicts such a principle ${ }^{(15)}$.

The right of users to be informed about the reasons medication or supplies are late is included in law $11.347 / 06$, that provides for the free distribution of medication and supplies necessary for the application and monitoring of capillary glucose for users attending DM educational programs. From this perspective, law $11.347 / 06$ article 3 ensures that people with DM have the right to demand information, in case medication and material is late, from the city health authority ${ }^{(3)}$.

Therefore, we found in our study that there is a 
lack of knowledge on the part of most of the DM users concerning their healthcare rights and also of current laws on DM in relation to the free distribution of medication and supplies. On the other hand, the interviewees' reports also revealed that they use the benefits that accrue from DM legislation though they do not know their rights, which limits the social control exercised by the community as well as limiting the demand of their rights in situations in which these are being threatened or violated.

\section{The unconscious exercise of rights by DM users}

The bioethical principle of justice that provides a fair distribution of healthcare resources, in addition to incorporating utilitarian and equalitarian standards in a coherent way also guides our health system(7). Hence, such a principle defends the view that all health services users should have equalitarian access to health services and the same opportunities of access to information that are necessary for health promotion, prevention and recovery.

Even though most of the interviewees report (a lack of) knowledge in relation to the rights as individuals with DM, some, over the course of the interview, acknowledge their rights, as shown in the reports that follow:

I don't know anything yet ... [silence] Oh, I guess that getting the insulin at the unit, right? And the test strips, right? I get them there. (E1)

I don't know... I guess that the medications, consultations in the health unit, I guess it's that, I think. (E4)

Rights... Look, I have the right to a dignified treatment, I guess it is the follow-up, whether it is held in a private outpatient clinic or through the SUS, it's a right acquired from the government program, these would be the rights. (E7)

Personal choices are also important since not every individual need becomes a demand in the health services. Hence, not all users have the same needs and therefore, they use the benefits differently as the following reports shows:

Rights? I know they give you medication free of charge, but I've never went after those, because I buy them, you know? I'd rather buy mine and leave these free medication to those who don't have the means to buy them, you know? (E12)

This report implicitly shows a feeling of solidarity, which can be defined as a feeling individuals have of belonging to something bigger. This feeling represents a significant part of one's personal identity and confers a sense of accomplishment that exceeds one's individuality and permits one to acknowledge the needs of other people economically disadvantaged. At the same time, it is possible to perceive a certain naturalization of such situations as patients acknowledge the available service as a favor or donation and not as a right(16).

In a study carried out in Itajaí, SC, Brazil(17), which analyzed the trajectories of users who received medication through a mandate against the State of Santa Catarina, Brazil and their motivations and perceptions concerning this means to get access to medications, revealed that these individuals tried to acquire the medication asking politicians, who in turn have political interests. This situation was also seen in the following reports:

The physician at the health unit is a candidate for councilor in my city, so she gave me a prescription for six months. So, during six months I go there and get it [medication]. It is valid for six months. (E4)

Now, it's election time, whatever you need you get. You go to a politician and say: look I need this and they say: I'll get it to you, especially those who are physicians you known? So, I see there are ulterior motives, there's always some interest. (E5)

According to this study, such relationships among politicians, physicians, and health users reveal the perception that the granting of rights is oftentimes used as a bargaining tool, which reinforces the social perception that it is actually a "favor". Hence, somebody with authority and power should intervene so that users achieve benefits legally ensured but which they have not yet acknowledged as a right.

We also identified that the health services users, unaware of their rights, make use of their personal friendship with influential people to achieve what they want. It seems to reflect a pre-established model in Brazilian institutions and entrenched in popular culture in which the "Brazilian way" is used as a manner to obtain personal benefits ${ }^{(18)}$.

Go and talk to the mayor really, thank God I have this fortune... [Laugh] I can go and talk directly to him if I want to, we are friends, studied together. (E3)

Health professionals should incrementally continue educational programs aiming to monitor the course of chronic complications in DM and also develop interventions that encourage changes in lifestyle, which would permit the understanding of which factors interfere and/or facilitate achieving good metabolic control(19-20). On the other hand, we observe the need to provide sufficient information for DM patients so they make the best decision in relation to their treatment in an autonomous manner, since users with DM are not fully aware of their rights in our context. 


\section{Final Considerations}

Most of the health services users are unaware of their rights despite advancements achieved by public policies, although they use these rights to acquire medication and supplies for their treatments. It is important to stress that health professionals have a difficult task before them: to promote the awareness of users with DM concerning their rights, especially that benefits exist and should be acknowledged not as "favors" but as the result of health policies that provide legal instruments for their implementation.

Therefore, education is an indispensable tool in this awareness process. Health education seeks to raise awareness - which requires more than simply informing - for users with DM of their rights and develop objective conditions for their implementation. Hence, health professionals need to know the benefits that accrue from laws and that go beyond freely, regularly and equitably distributing supplies, glucometers and medications to all DM users. The need to promote sufficient information to users with DM so they can autonomously make the best decision in relation to their treatment implies the importance of training professionals to educate, guide, and respect the capacity of users to be autonomous.

If users do not have necessary and sufficient information, they do not feel capable of claiming and/or fighting for their rights, which hinders the full exercise of their autonomy. Promoting the quality of healthcare through respecting the rights of users and especially through informative, beneficent and fair actions, that result in the increased financial autonomy of users, should be a goal to be pursued by health professionals.

It is important to highlight that changing behavior in relation to health practices is a difficult task because it requires health professionals to have time, resources and qualifications. We stress the importance of government leaders and health authorities promoting innovative public policies in order to recognize the educational approach as a light technology to be valued and implemented in health services.

The results systematized by this study allow promoting knowledge produced by recent studies, especially in the context of the Latin American Journal of Nursing as it gives voice to health services users and inquires of them about their awareness of their rights as individuals with DM.

Given the obtained results, further studies to deepen aspects not addressed in this study, especially subjective dimensions of the relationship between users and health professionals, are needed. Therefore, evidence found here can be further expanded and discussed in light of new knowledge.

When we take into account that nursing represents a link between users and current healthcare models, we verify that providing appropriate information to health service users is a role of nursing. Hence, we expect that the results related to the knowledge of health service users with DM about their rights and benefits that accrue from current law, can contribute to qualified nursing care, responsible and coherent with the bioethical principles of beneficence, nonmaleficence, justice and respect for the autonomy of users.

\section{References}

1. International Diabetes Federation. Complicações do diabetes e educação. Diabetes Clín. 2002;6(3):217-20.

2. Organização Mundial de Saúde (OMS). Cuidados inovadores para condições crônicas: componentes estruturais de ação: relatório mundial. Brasília (DF): OMS; 2003.

3. Lei $n^{\circ} 11.347$ de 27 de setembro de 2006 (BR). Dispõe sobre a distribuição gratuita de medicamentos e materiais necessários à sua aplicação e à monitoração da glicemia capilar aos portadores de diabetes inscritos em programas de educação para diabéticos. Diário Oficial da União, 28 setembro. Brasília (DF): Imprensa Oficial; 2006.

4. Portaria n 2583 de 10 de outubro de 2007 (BR). Define elenco de medicamentos e insumos disponibilizados pelo SUS nos termos da Lei n²11347, de 2006, aos usuários portadores de diabetes mellitus. Diário Oficial da União, 15 outubro 2007. Brasília: Imprensa Oficial; 2007.

5. Pessini L, Pelicioni MCF, Campinas LLLS, Pelicioni AF. Educação e promoção da saúde: bases para a cidadania e a qualidade de vida. O Mundo da Saúde. 2007;3:317-9.

6. Dallari SG. A participação popular e o direito à saúde no Sistema Nacional de Saúde Brasileiro. Rev Direito Sanit. 2005;6:9-24.

7. Beauchamp TL, Childress JF. Princípios de Ética Biomédica. 4a ed. São Paulo: Edições Loyola; 2002.

8. Selli L, Papaléo LK, Meneghel S, Torneros JZ. Técnicas educacionales en el tratamiento de la diabetes. Cad Saúde Pública. 2005;21(5):1366-72.

9. Garrafa V, Oselka G, Diniz D. Saúde pública, bioética e equidade. Bioética. 1997;5(1):27-33.

10. Minayo MCS. O desafio do conhecimento: pesquisa qualitativa em saúde. $4^{a}$.ed. São Paulo 
(SP): Hucitec; 1996.

11. Costa VT, Lunardi VL, Lunardi WD Filho. Autonomia versus cronicidade: uma questão ética no processo de cuidar em Enfermagem. Rev Enferm UERJ. 2007;15(1):53-8.

12. Pellegrini A Filho. Pesquisa em saúde, política de saúde e eqüidade na América Latina. Ciênc Saúde Colet. 2004;9(2):339-50.

13. Bosi MLM, Affonso KC. Cidadania, participação popular e saúde: com a palavra, os usuários da rede pública de serviços. Cad Saúde Pública. 1998;14(2):355-65.

14. Berlinguer G. Bioética cotidiana. Brasília: Editora Universidade de Brasília; 2004.

15. Selli L, Vial EA. Justiça como autonomia dos indivíduos. Rev Bras Bioética. 2006;2(3):328-40.

16. Traverso-Yépez M, Morais NA. Reivindicando a subjetividade dos usuários da Rede Básica de Saúde: para uma humanização do atendimento. Cad Saúde Pública. 2004;20(1):80-8.

17. Mafra AC. Que direito? Trajetórias e percepções dos usuários no processo de acesso a medicamentos por mandatos judiciais em Santa Catarina. In: $4^{\circ}$ Congresso Brasileiro de Ciências Sociais e Humanas em Sáude, 2007, Salvador. Anais Equidade, Ética e Direito à Saúde: desafios à Saúde Coletiva na mundialização. Rio de Janeiro: Abrasco; 2007.

18. Damatta R. O que faz o brasil, Brasil? Rio de Janeiro: Rocco; 1998.

19. Santos ECB, Zanetti ML, Otero LM, Santos MA. O cuidado sob a ótica do paciente diabético e de seu principal cuidador. Rev. Latino-Am. Enfermagem. 2005;13(3):397-406.

20. Otero LM, Zanetti ML, Teixeira CRS. Sociodemographic and clinical characteristics of a diabetic population at a primary level health care center. Rev. Latino-Am. Enfermagem. 2007;15(spe):768-73. 